\title{
A comparison study between fuzzy PWM and SVM inverter in NSMC control of stator active and reactive power control of a DFIG based wind turbine systems
}

\author{
Habib Benbouhenni \\ National Polytechnique School of Oran Maurice Audin, Oran, Algeria
}

\begin{tabular}{l}
\hline \hline Article Info \\
\hline Article history: \\
Received Nov 4, 2018 \\
Revised Dec 28, 2018 \\
Accepted Mar 6, 2019 \\
\hline Keywords: \\
Neuro-sliding mode control \\
Fuzzy pulse width modulation \\
Doubly fed induction generator \\
Space vector modulation \\
Wind turbine systems
\end{tabular}

\begin{abstract}
In this work, we present a comparative study between space vector modulation (SVM) and fuzzy pulse width modulation (FPWM) technique in neuro-sliding mode control (NSMC) of stator reactive and stator active power control of the doubly fed induction generator (DFIG) for wind turbine system (WTS). Two controls approach using NSMC-SVM and NSMCFPWM control scheme are proposed and compared. The validity of the proposed control techniques is verified by simulation tests of a DFIG. The reactive power, rotor current and stator active power is determined and compared in the above strategies. The obtained results showed that the proposed NSMC with FPWM strategy has stator reactive and active power with low powers ripples and low rotor current harmonic distortion than SVM technique.
\end{abstract}

Copyright $\odot 2019$ Institute of Advanced Engineering and Science. All rights reserved.

Corresponding Author:

Habib Benbouhenni,

Department of Electrical Engineering,

National Polytechnique School of Oran Maurice Audin, Oran, Algeria.

Email: habib0264@gmail.com

\section{INTRODUCTION}

In modulation techniques, Pulse Width Modulation (PWM) strategy has drawn much attention from research groups and industry. However, this strategy is simple scheme and easy to implement compared to Space Vector Modulation (SVM). On the other hand, this strategy gives more Total Harmonic Distortion (THD) of current, electromagnetic torque ripple, rotor flux ripple and powers ripples of the Doubly Fed Induction Generator (DFIG) based Wind Turbine System (WTS).

In order to improve the conventional PWM performances, a complimentary use of the Fuzzy Logic Controller (FLC) is proposed. The principle of fuzzy pulse width modulation (FPWM) is like to traditional PWM technique. This strategy is detailed in [1]. On the other hand, this proposed technique is simple modulation scheme and easy to implement. This strategy reduced THD value of rotor current, electromagnetic torque ripple and powers ripples of the DFIG.

Since doubly fed induction generator is one of the most popular variable speed WTs in use nowadays. It is normally fed by a voltage source inverter [2]. The principal advantage of the DFIG is that rotor side converter (RSC) is only sized for $30 \%$ of rated power compared to other generators used in variable speed wind energy conversion systems (WECSs) [3]. Various control techniques have been proposed for studying the behaviour of DFIG based WECSs during normal operation. In [4], the author proposed the direct torque control to regulate the electromagnetic torque and flux of the DFIG. Similar to direct torque control, a direct power control of doubly fed induction generator-based WECS has proposed [5, [6]. In [7], direct torque control technique based on second order sliding mode controller has been proposed. Indirect vector control (IVC) and direct vector control (DVC) was designed to control the reactive and active power of the DFIG [8]. In [9], a reactive and active power neuro-second order sliding mode 
controller and neural space vector modulation strategy (NSVM) were combined to replace the traditional proportional-integral (PI) controllers and space vector modulation (SVM). SVM and fuzzy logic controller (FLC) are combined to regulate the electromagnetic torque and stator active power [10]. In [11], the author proposes a new three-level space vector modulation based on neural controller to control DFIG-based WTSs. In [12], [13], an intelligent control (IC) was designed to control stator active and reactive power of DFIGbased WTSs. Robust control (RC) has been proposed for doubly fed induction generator [14], [15]. In [16], the author proposes the backstepping control (BC) to regulate the reactive and stator reactive power of DFIGbased WECSs. In literature [17], vector control (VC) is the most popular control techniques used in the DFIG based WTSs. VC control using PI controllers is the classical control strategy used for DFIG-based WTSs. In this technique, the decoupling between q-axis and d-axis current is achieved with feedforward compensation, and thus the DFIG model becomes less difficult and conventional PI controllers can be used. This control scheme is a simple and easy implement compared to other control schemes. On the other hand, this control gives more electromagnetic torque ripple, rotor flux ripple, powers ripples and big THD of rotor current of the DFIG-based WECSs.

In order to overcome the drawbacks of the $\mathrm{VC}$ control, sliding mode control has been presented [18], [19]. In control systems, sliding mode control (SMC) is a type of variable structure control (VSC) that possesses robust characteristics to system disturbances and parameter uncertainties. The SMC technique was proposed by Utkin in 1977 [20]. The main advantages of SMC strategy, including robustness, finite-time convergence, and reduced-order compensated dynamics, are demonstrated on numerous exemples and simulation plots. On the other hand, the SMC has a major inconvenience which the chattering effect is created by the discontinuous part of the control. In [21], the author proposes an SMC based on FLC to reduce the chattering phenomenon and powers ripples of the DFIG-based WECSs. A second order sliding mode control was designed to control DFIG-based DRWT (dual-rotor wind turbine) [22]. In this paper, neurosliding mode controller (NSMC) has been proposed.

A neural network (NNs) is a technique based on engineering experience and observations. In NN controller, an exact mathematical model is not necessary. The design of an SMC incorporating neural control helps in achieving reduced chattering, simple control, easy to implement, and robustness against disturbances and nonlinearities.

In this work, we apply the neuro-sliding mode control scheme on the doubly fed induction generator-based WTSs using fuzzy pulse width modulation technique compared to the conventional space vector modulation technique.

\section{FUZZY PULSE WIDTH MODULATION}

In modulation strategies, the pulse width modulation strategy is widely used in control AC machine drives. This modulation strategy is detailed in [1]. In addition, this strategy is simple algorithm and easy to implement. However, this technique has the following drawbacks. This strategy gives more harmonic distortion of current and powers ripples of the DFIG. Figure 1 shows the principle of the pulse width modulation strategy of the two-level inverter.

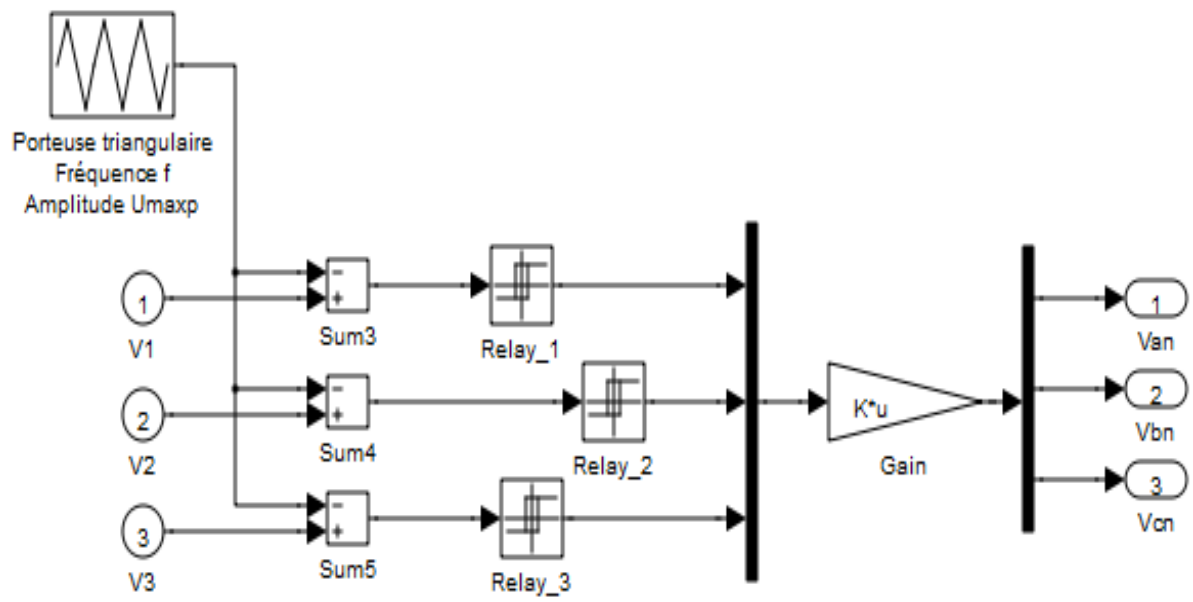

Figure 1. Block diagram of PWM technique 
In order to improve the two-level PWM performances a complimentary use of Fuzzy Logic (FL) controller is proposed. Fuzzy logic controllers have been used in many areas after fuzzy set theory was first introduced by Zadeh [23]. In FL control does not need a mathematical model. Traditionally, fuzzy variables have been adjusted by expert knowledge. On the other hand, the design of FL controller has relied on trial and error. In addition, the FL control is a simple control and easy to implement compared to classical controllers.

One way to improve pulse width modulation performance is to combine it with FL to form a fuzzy pulse width modulation (FPWM). The design of a pulse width modulation incorporating FL control help in achieving reduced the THD value of rotor current and powers ripples, simple algorithm, easy to implement, and robust technique compared to classical PWM and space vector modulation. The principal of the FPWM strategy is exposed in Figure 2.

The FLC contains three blocks: fuzzy rule base, fuzzification and defuzzification. However, the FLC rules are developed using linguistic changes that are formulated in the form of «IF THEN » rules. The Table 1 shows these rules [24], [25]. The Table 2 shows the parameters of FLC for the FPWM strategy.

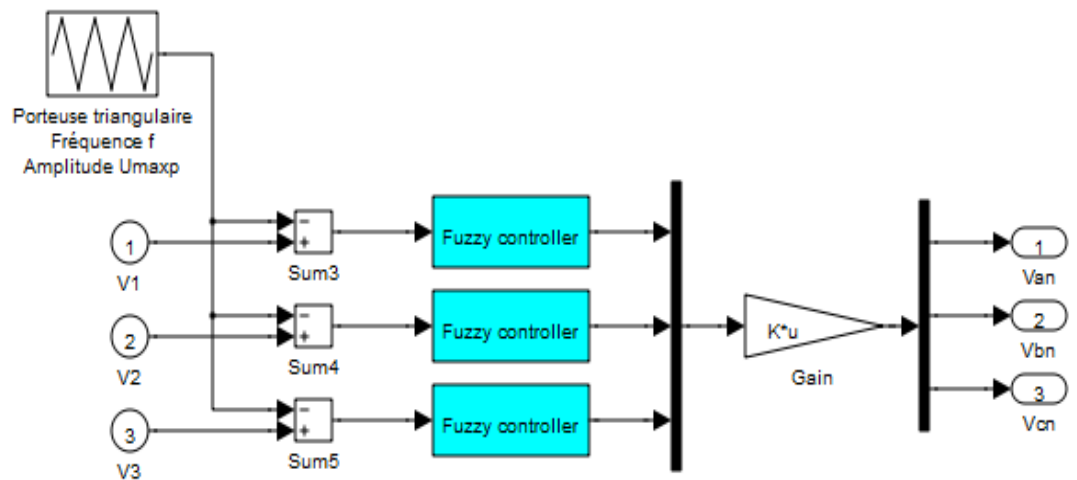

Figure 2. Block diagram of FPWM strategy

Table 1. Matrix of inference

\begin{tabular}{cccccccc}
\hline $\mathrm{e}$ & \multirow{2}{*}{$\mathrm{NB}$} & $\mathrm{NM}$ & $\mathrm{NS}$ & EZ & PS & PM & PB \\
\hline $\mathrm{e}$ & & & & & & & \\
\hline NB & NB & NB & NB & NB & NM & NS & EZ \\
NM & NB & NB & NB & NM & NS & EZ & PS \\
NS & NB & NB & NM & NS & EZ & PS & PM \\
EZ & NB & NM & NS & EZ & PS & PM & PB \\
PS & NM & NS & EZ & PS & PM & PB & PB \\
PM & NS & EZ & PS & PM & PB & PB & PB \\
PB & EZ & PS & PM & PB & PB & PB & PB \\
\hline
\end{tabular}

Where:

NB: Negative Big

NS: Negative Small

PM: Positive Middle

EZ: Equal Zero

PB: Positive Big

PS: Positive Small

NM: Negative Middle

Table 2. Parameters of FLC

\begin{tabular}{cc} 
Table 2. Parameters of FLC \\
\hline Fis type & Mamdani \\
And method & Min \\
Or method & Max \\
Implication & Min \\
Aggregation & Max \\
Defuzzification & Centroid \\
\hline
\end{tabular}


The block diagram of FLC based on hysteresis comparators is shown in Figure 3. The membership function definition for the input changes "Error in comparators hysteresis" and "Change in Error of comparators hysteresis" is given by Figure 4.

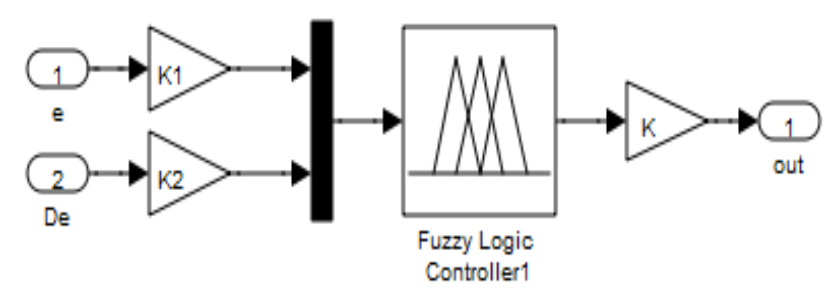

Figure 3. Fuzzy command of FPWM strategy
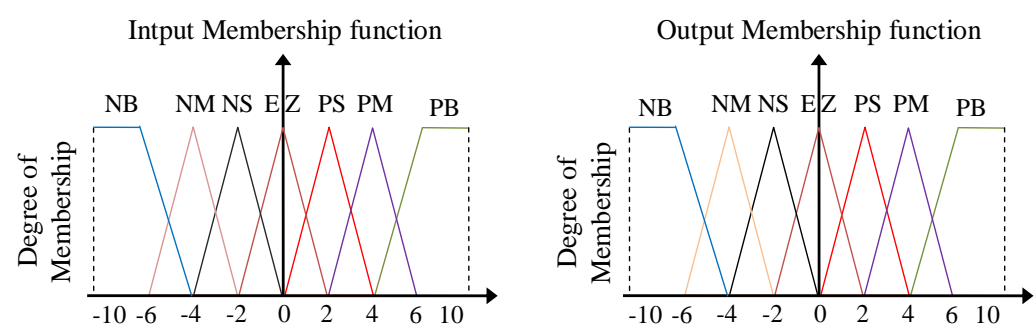

Figure 4. Fuzzy sets and its memberships functions

\section{MODEL OF TURBINE}

The WT input power usually is $[26,27]$ :

$$
P_{\max }=0.5 \rho \pi R^{2} V_{\text {vent }}^{3}
$$

Where, $\rho$ : The air density.

$\mathrm{V}_{\text {vent }}$ : The wind speed $(\mathrm{m} / \mathrm{s})$.

$\mathrm{P}_{\max }$ : The maximum power in (watts).

The mechanical power is given by:

$$
\begin{aligned}
& P_{m}=0.5 \cdot C_{p}(\lambda) \cdot \rho \pi R^{2} V_{v e n t}^{3} \\
& \lambda=\frac{R \cdot \Omega_{1}}{V_{1}}
\end{aligned}
$$

Where:

$\mathrm{R}$ : The radius of the turbine in $(\mathrm{m})$.

$\mathrm{C}_{\mathrm{p}}$ : The aerodynamic coefficient of power.

$\lambda$ : The tip speed ratio.

$$
\begin{aligned}
& C_{p}(\beta, \lambda)=C_{1} \cdot\left(\frac{C_{2}}{\lambda_{i}}-C_{3} . \beta-C_{4}\right) \cdot \exp \left(\frac{-C_{5}}{\lambda_{i}}\right)+C_{6 . \lambda} \\
& \frac{1}{\lambda_{i}}=\frac{1}{\lambda+0.08 \cdot \beta}-\frac{0.035}{\beta^{3}+1}
\end{aligned}
$$

Where

$\mathrm{C}_{1}: 0.5176, \mathrm{C}_{2}=116, \mathrm{C}_{3}=0.4, \mathrm{C}_{4}=5, \mathrm{C}_{5}=21, \mathrm{C}_{6}=0.0068$.

$\beta$ : The blade pitch angle in a pitch-controlled wind turbine. 


\section{MODELING THE DFIG}

The modeling of the doubly fed induction generator is described in the $q$ - $d$ Park reference frame. The following equation system describes the total generator model [28, 29] .

$$
\left\{\begin{array}{l}
\mathrm{V}_{\mathrm{ds}}=\mathrm{R}_{\mathrm{s}} \mathrm{I}_{\mathrm{ds}}+\frac{\mathrm{d}}{\mathrm{dt}} \psi_{\mathrm{ds}}-\omega_{\mathrm{s}} \psi_{\mathrm{qs}} \\
\mathrm{V}_{\mathrm{qs}}=\mathrm{R}_{\mathrm{s}} \mathrm{I}_{\mathrm{qs}}+\frac{\mathrm{d}}{\mathrm{dt}} \psi_{\mathrm{qs}}+\omega_{\mathrm{s}} \psi_{\mathrm{ds}} \\
\mathrm{V}_{\mathrm{dr}}=\mathrm{R}_{\mathrm{r}} \mathrm{I}_{\mathrm{dr}}+\frac{\mathrm{d}}{\mathrm{dt}} \psi_{\mathrm{dr}}-\omega_{\mathrm{r}} \psi_{\mathrm{qr}} \\
\mathrm{V}_{\mathrm{qr}}=\mathrm{R}_{\mathrm{r}} \mathrm{I}_{\mathrm{qr}}+\frac{\mathrm{d}}{\mathrm{dt}} \psi_{\mathrm{qr}}+\omega_{\mathrm{r}} \psi_{\mathrm{dr}}
\end{array}\right.
$$

Where:

$I_{d r}$, and $I_{q r}:$ is the rotor currents.

$I_{d s}$ and $I_{q s}:$ is the stator currents.

$V_{d r}$, and $V_{q r}$ : is the rotor voltages.

$V_{q s}$ and $V_{d s}:$ is the stator voltages.

$R_{r}:$ is the resistances of the rotor windings.

$R_{s}:$ is the resistances of the stator windings.

The flux can be expressed as:

$$
\left\{\begin{array}{l}
\psi_{d s}=L_{s} I_{d s}+M I_{d r} \\
\psi_{q s}=L_{s} I_{q s}+M I_{q r} \\
\psi_{d r}=L_{r} I_{d r}+M I_{d s} \\
\psi_{q r}=L_{r} I_{q r}+M I_{q s}
\end{array}\right.
$$

Where:

$\psi_{d r}$ and $\psi_{\mathrm{qr}}$ : is the rotor fluxes. $\psi_{d s}$ and $\psi_{q s}$ : is the stator fluxes. $L_{r}$ : is the inductance own rotor $L_{s}:$ is the inductance own rotor $M:$ is the mutual inductance.

The powers are expressed as:

$$
\left\{\begin{array}{l}
P_{s}=\frac{3}{2}\left(V_{d s} I_{d s}+V_{q s} I_{q s}\right) \\
Q_{s}=\frac{3}{2}\left(V_{q s} I_{d s}-V_{d s} I_{q s}\right)
\end{array}\right.
$$

Where:

$\mathrm{P}_{\mathrm{s}}:$ is the active power.

$\mathrm{Q}_{\mathrm{s}}:$ is the reactive power.

The electromagnetic torque is expressed as:

$$
\begin{aligned}
& T_{e}=p M(\text { Idr.Iqs }- \text { Iqr.Ids }) \\
& T_{e}=T_{r}+J \cdot \frac{d \Omega}{d t}+f \cdot \Omega
\end{aligned}
$$


Where:

$T_{r}$ : is the load torque.

$\mathrm{T}_{\mathrm{e}}$ : is the torque.

$\Omega$ : is the mechanical rotor speed.

$J:$ is the inertia.

$f:$ is the viscous friction coefficient.

$\mathrm{p}$ : is the number of pole pairs.

\section{NEURO-SLIDING MODE CONTROL}

The main objective of using NSMC is to develop a robust control of stator reactive and active power of the DFIG-based WECS. In our system, the stator active power and reactive are respectively controlled by $V_{q r}$ and $V_{d r}$. However, sliding mode control (SMC) is a nonlinear control strategy featuring remarkable properties of accuracy, robustness, and easy tuning and implementation. This strategy based on the theory of variable structure systems (VSS), has attracted a lot of research on command systems for the last two decades [30]. In [31], a sliding mode controller was designed to regulate the stator active power and reactive power of the DFIG-based WTSs. Nevertheless, this technique has an essential disadvantage, which is the chattering phenomenon caused by the discontinuous command action. On the other hand, chattering phenomenon could be reduced or suppressed using the different strategy such as,
a. Dynamic extension.
b. Non-linear gains.
c. Higher order sliding mode control.
d. Fuzzy logic control.
e. Neural networks.

Neural networks (NNs) are a technique based on engineering experience and observations. In neural networks, an exact mathematical model is not necessary. In order to eliminate the chattering phenomenon and minimize the powers ripples, we propose to use neuro-sliding mode control.

The neuro-sliding mode control (NSMC) is a modification of the sliding mode controller, where the switching controller term sat $(\mathrm{S}(\mathrm{x}))$, has been replaced by a neural control input as given belew.

$$
V_{d q}^{c o m}=V_{d q}^{e q}+V_{d q}^{\text {Neural }}
$$

The proposed neuro-sliding mode control, which is designed to command the stator reactive and stator active power of the DFIG-based WECSs is shown in Figure 5. The structure of SMC based on the NNs controller is shown in Figure 6.

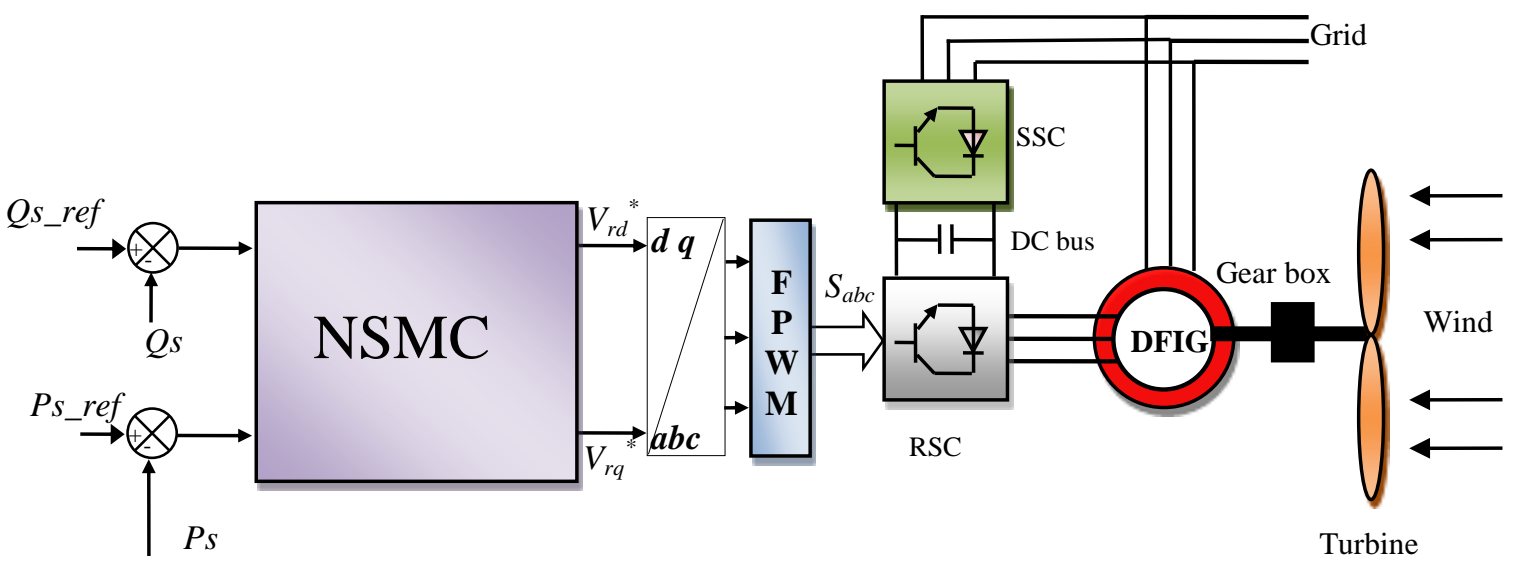

Figure 5. NSMC control of a DFIG using FPWM strategy 


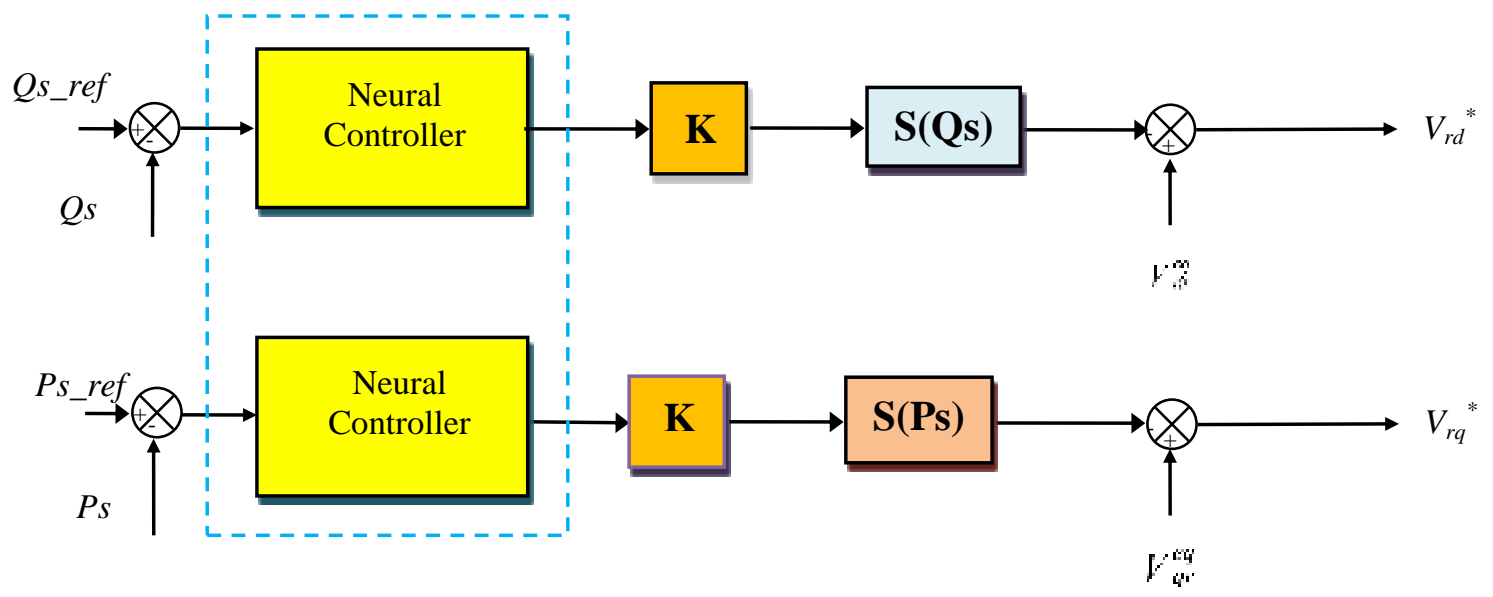

Figure 6. Block diagram of the NSMC technique

On the other hand, the training used is that of the algorithm, Gradiant descent with momentum \& Adaptive LR. The artificial neural networks controllers for the model system are shown in Table 3.

Table 3. Parameters of the Adaptative LR for Hysteresis Comparators

\begin{tabular}{cc}
\hline Parameters of the LM & Values \\
\hline Number of hidden layer & 12 \\
TrainParam.Lr & 0.005 \\
TrainParam.show & 50 \\
TrainParam.eposh & 2000 \\
Coeff of acceleration of convergence (mc) & 0.9 \\
TrainParam.goal & 0 \\
TrainParam.mu & 0.9 \\
Functions of activation & Tensing, Purling, gensim \\
\hline
\end{tabular}

The artificial neural networks model structure of the system is shown in Figure 7. The construction of layer 1 and layer 2 is shown in Figure 8 and Figure 9 respectively.

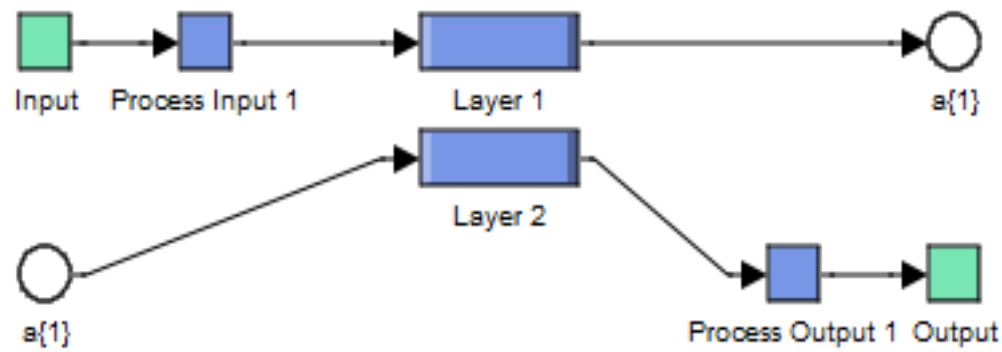

Figure 7. The ANN controller of the hysteresis comparators 


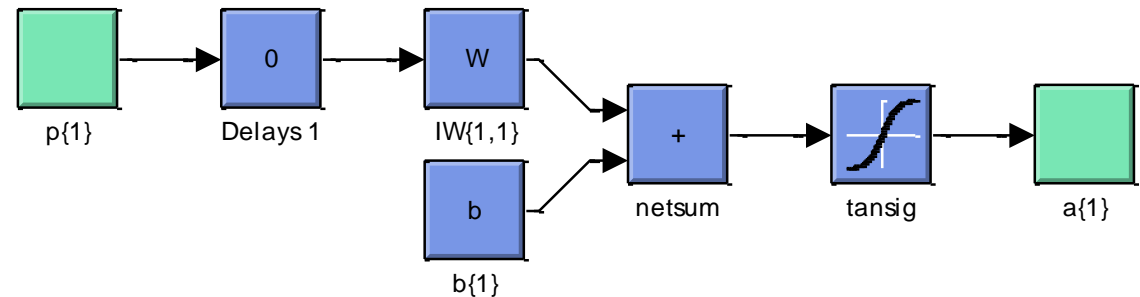

Figure 8. Block diagram of layer 1

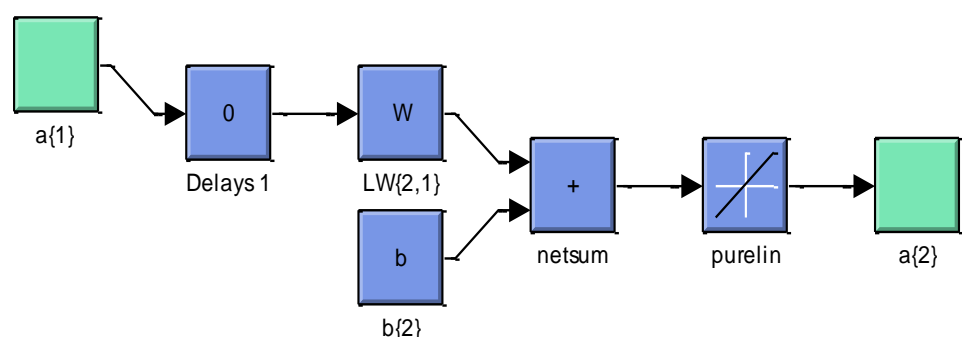

Figure 9. Block diagram of layer 2

\section{SIMULATION RESULTS}

The simulation results of three-level NSMC with FPWM technique of the DFIG are compared with NSMC control scheme with NSVM technique. The performance analysis is done with THD value, electromagnetic torque, stator active power and stator reactive power.

The DFIG used in this case study is a $1.5 \mathrm{MW}, 380 / 696 \mathrm{~V}$, two poles, $50 \mathrm{~Hz}$; with the following parameters: $\mathrm{Rs}=0.012 \Omega, \mathrm{Rr}=0.021 \Omega, \mathrm{Ls}=0.0137 \mathrm{H}, \mathrm{Lr}=0.0136 \mathrm{H}$ and $\mathrm{Lm}=0.0135 \mathrm{H}$.

The system has the following mechanical parameters: $J=1000 \mathrm{~kg} . \mathrm{m} 2$, fr=0.0024 Nm.s/rad.

\subsection{Reference Tracking Test (RTT)}

Figures 10-14 show the obtained simulation results. As it's shown in Figures 12-14, for the two NSMC control techniques, the stator reactive and stator active powers track almost perfectly their references values. Moreover, the NSMC-FPWM control reduced the electromagnetic torque and powers ripples compared to the NSMC-SVM (see Figures 15-17). On the other hand, Figures 10-11 show the total harmonic distortion of stator current of the DFIG for two NSMC control schemes. It can be clearly observed that the total harmonic distortion value is minimized for NSMC-FPWM (THD=0.24\%) when compared to NSMC control using SVM inverter (THD=0.68\%). 

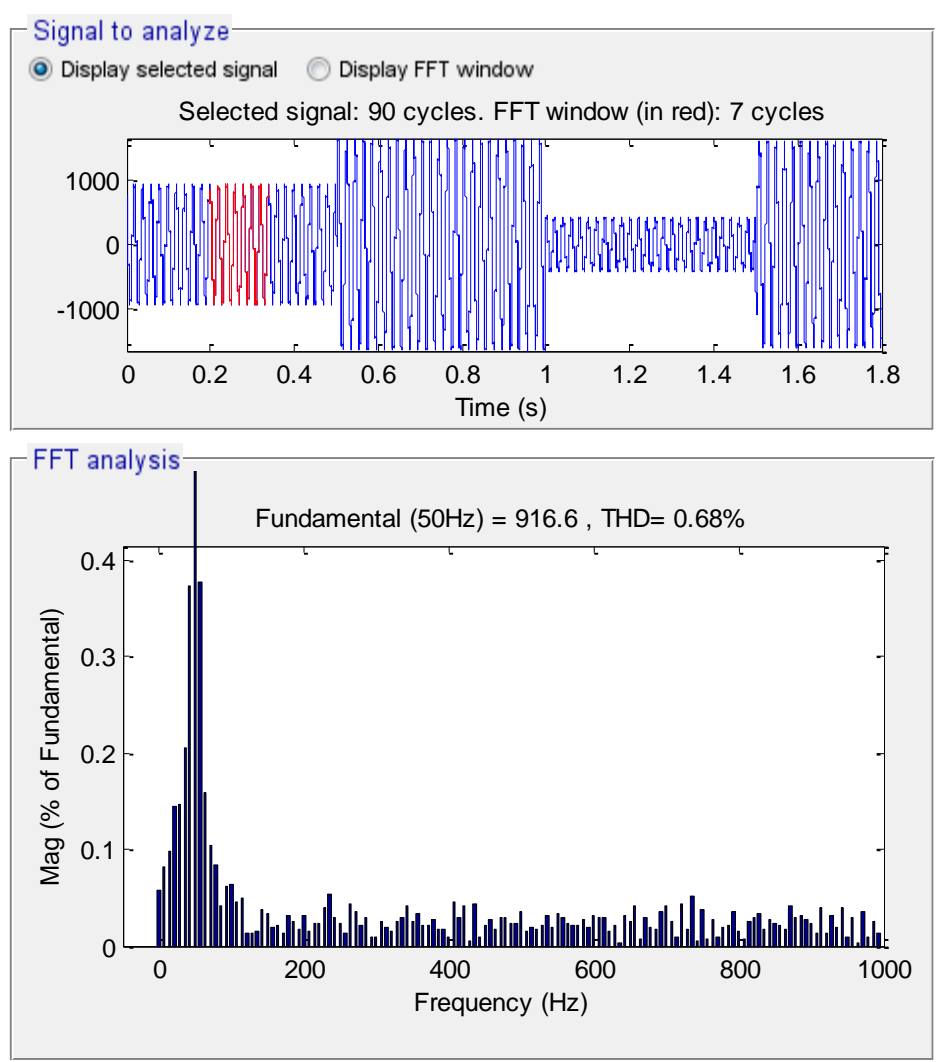

Figure 10. THD of rotor current for NSMC-SVM control
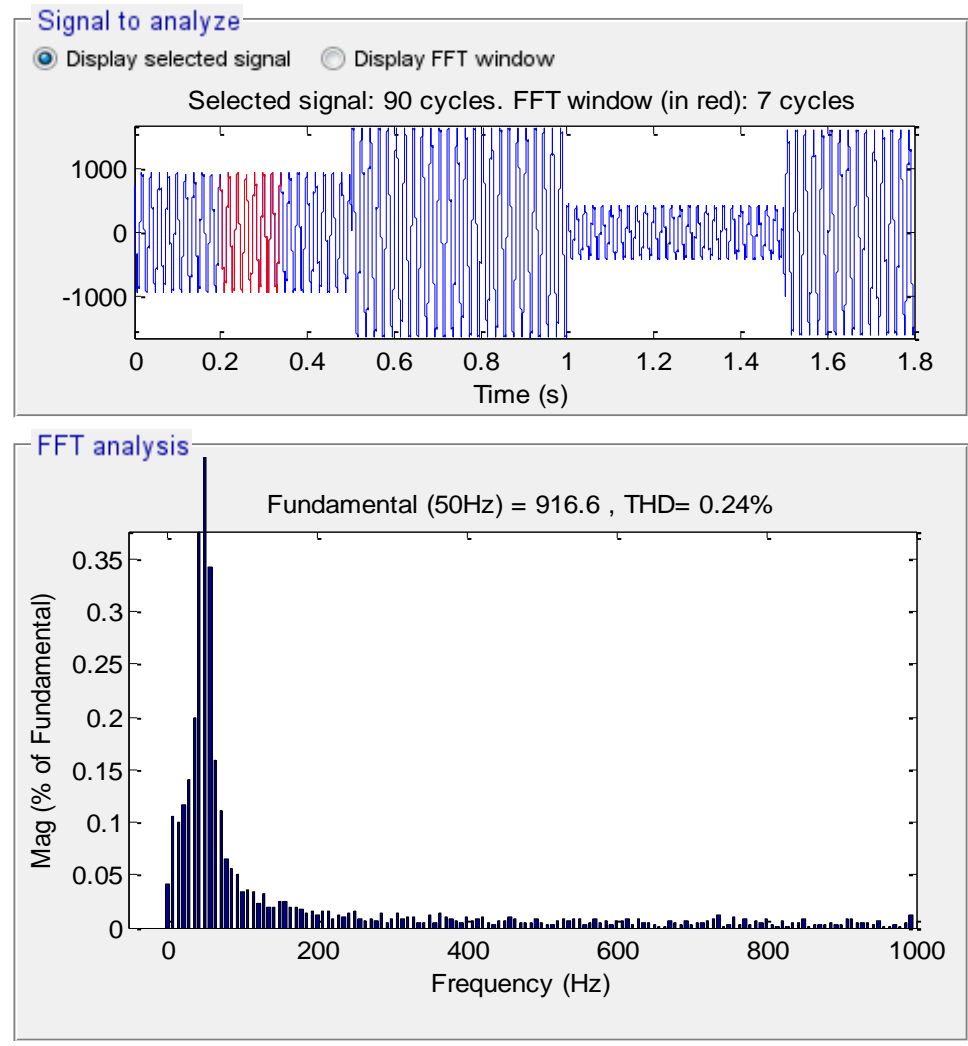

Figure 11. THD of rotor current for NSMC-FPWM control 


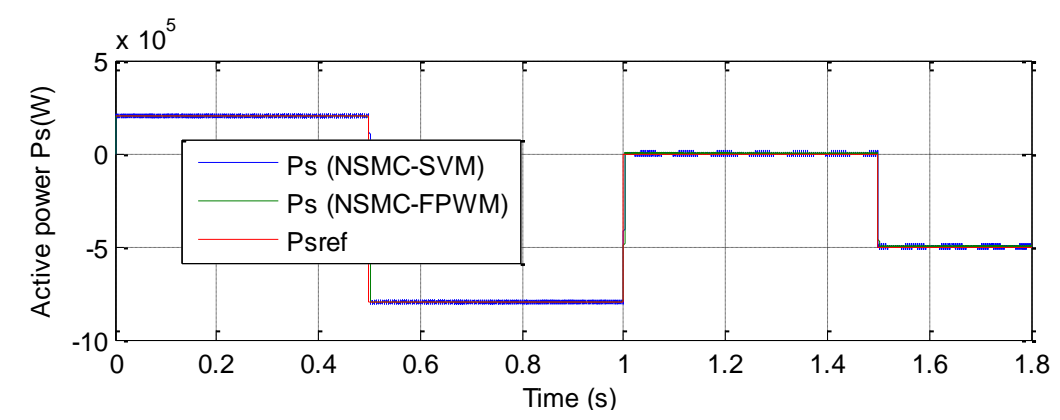

Figure 12. Stator active power

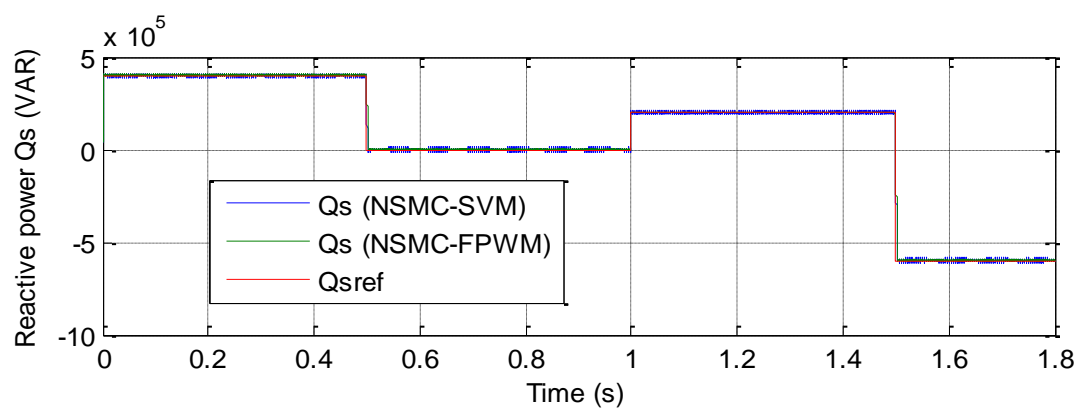

Figure 13. Stator reactive power

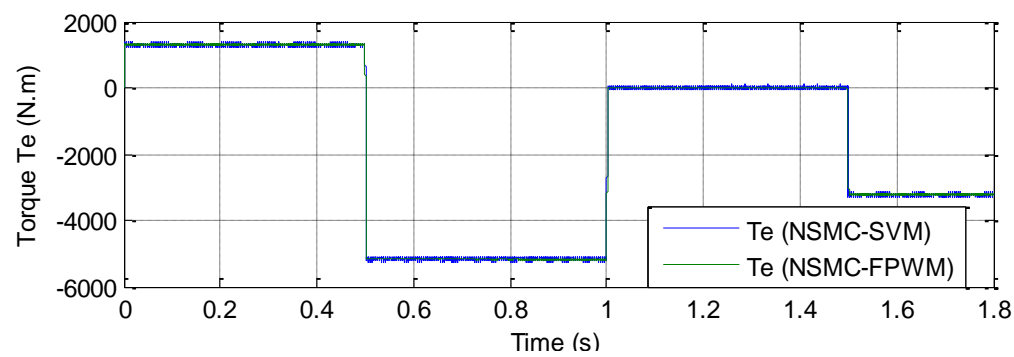

Figure 14. Electromagnetic torque power

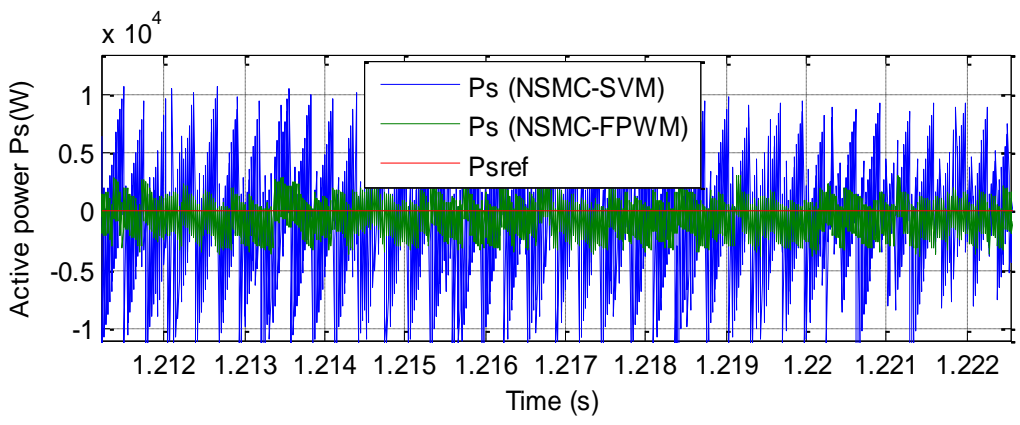

Figure 15. Zoom in the active power 


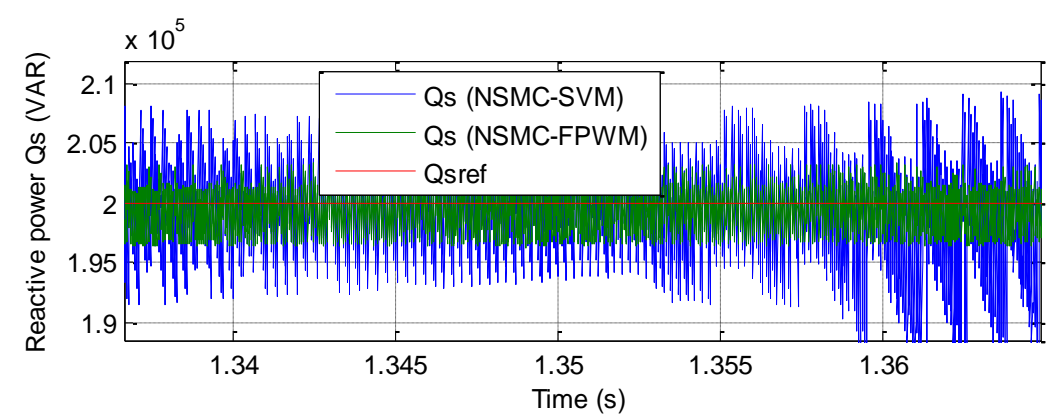

Figure 16. Zoom in the reactive power

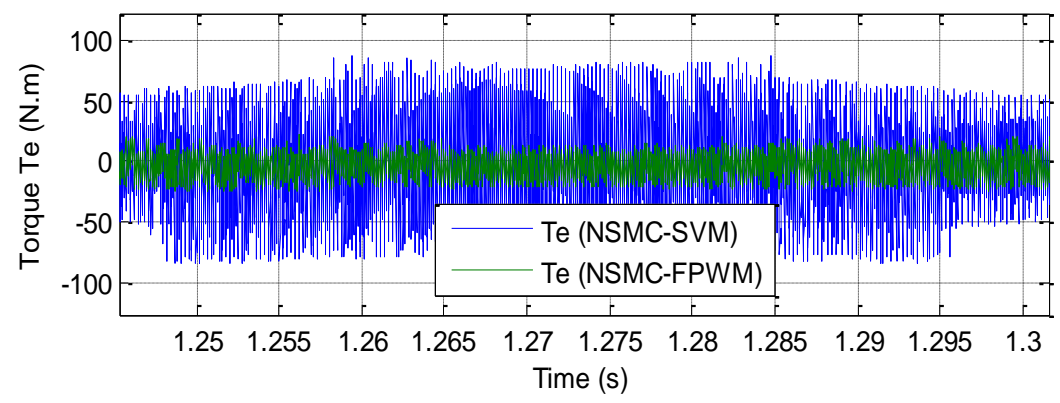

Figure 17. Zoom in the electromagnetic torque

\subsection{Robustness Test (RT)}

In this part, the nominal value of the $R_{r}$ and $R_{s}$ is multiplied by 2 , the values of inductances $L_{s}, M$, and $L_{r}$ are multiplied by 0.5 . Simulation results are presented in Figures. 18-22. As it's shown by these figures, these variations present an apparent effect on the electromagnetic torque, stator active and stator reactive powers. However, the effect appears more significant for the NSMC-SVM compared to NSMC-FPWM control scheme (see Figures. 23-25).

On the other hand, these results show that the THD value of rotor current in the NSMC-FPWM control has been reduced significantly. Table 4 shows the comparative analysis of THD value. Thus it can be concluded that the NSMC-FPWM control scheme is more robust than the NSMC-SVM control one.

Table 4. Comparative Analysis of THD Value

\begin{tabular}{ccc}
\hline \multirow{3}{*}{ Rotor current (Iar) } & \multicolumn{2}{c}{ THD (\%) } \\
\cline { 2 - 3 } & NSMC-SVM & NSMC-FPWM \\
& 1.36 & 0.48 \\
\hline
\end{tabular}



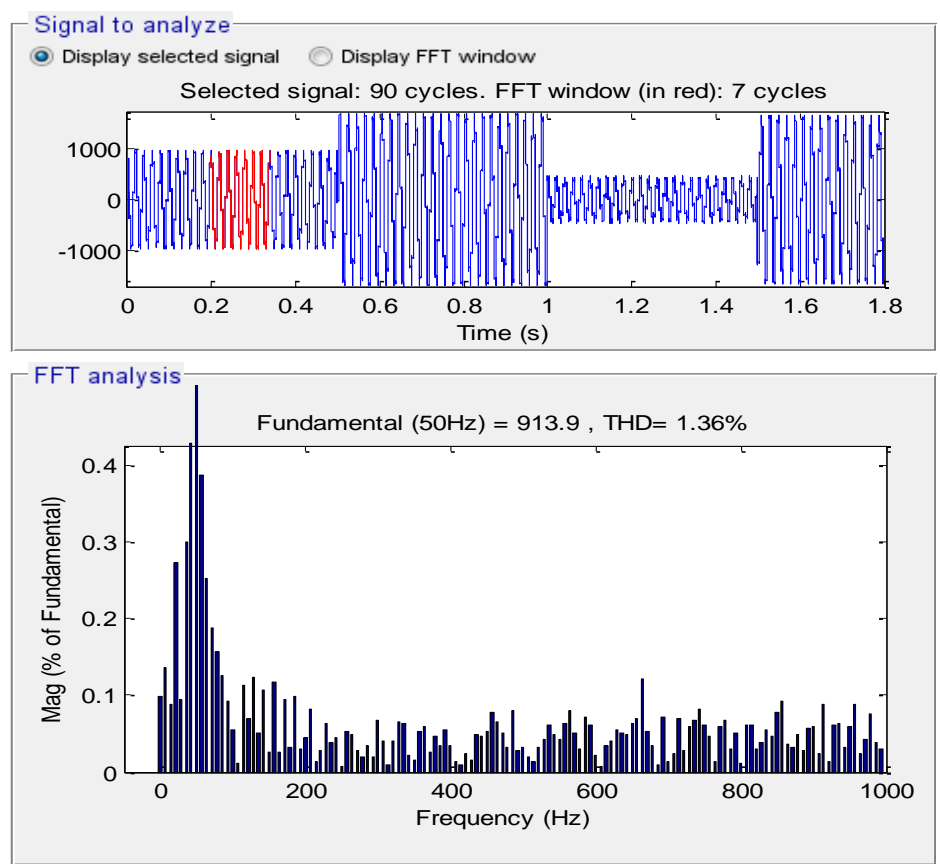

Figure 18. THD of rotor current for NSMC-SVM control
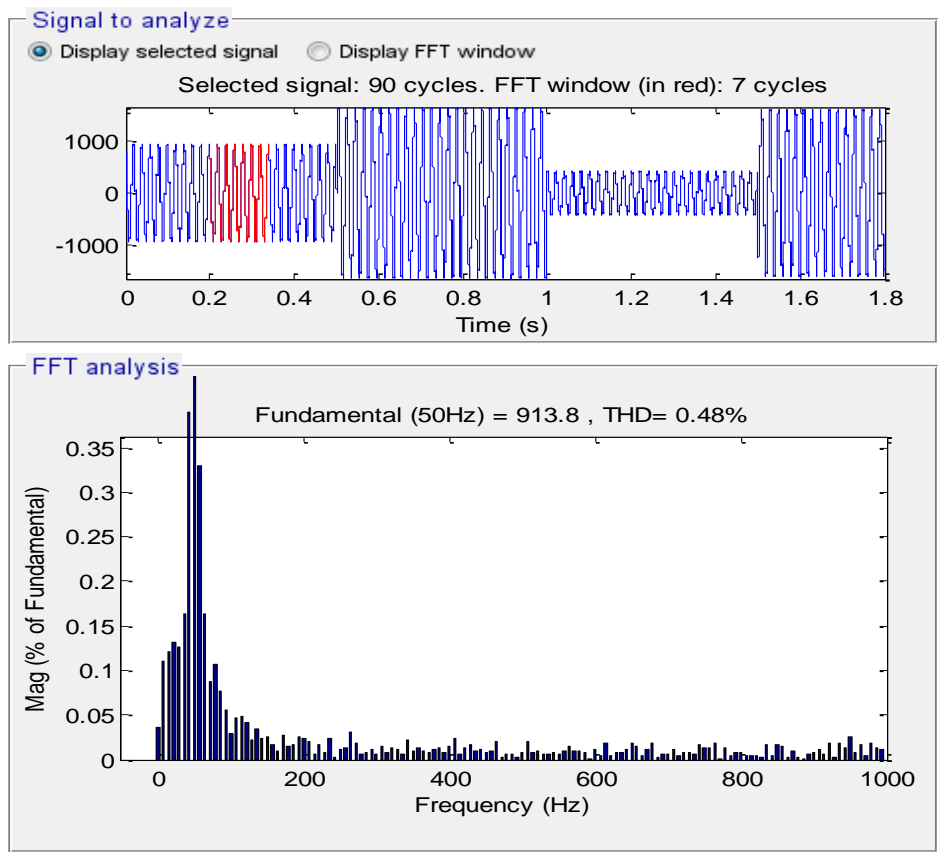

Figure 19. THD of rotor current for NSMC- FPWM control 


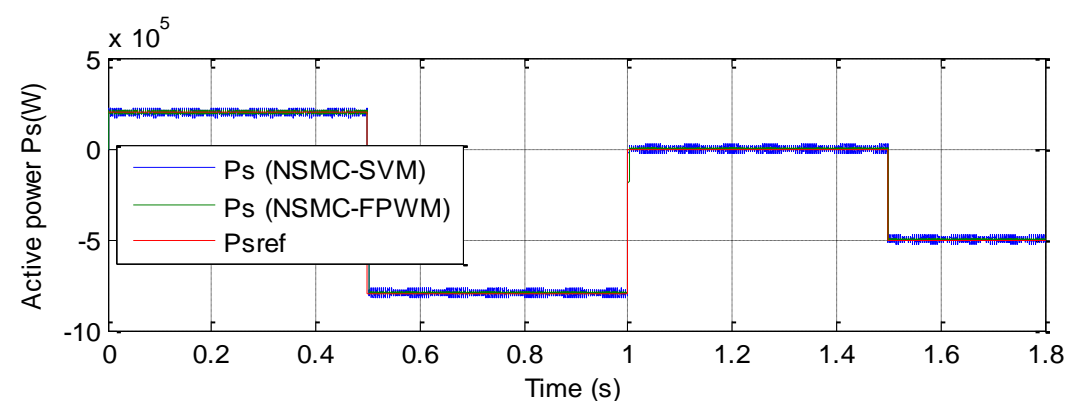

Figure 20. Stator active power

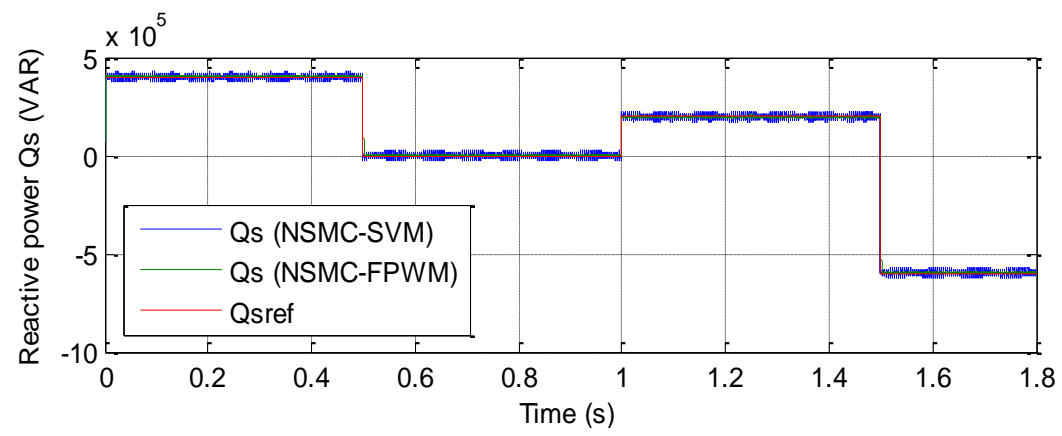

Figure 21. Stator reactive power

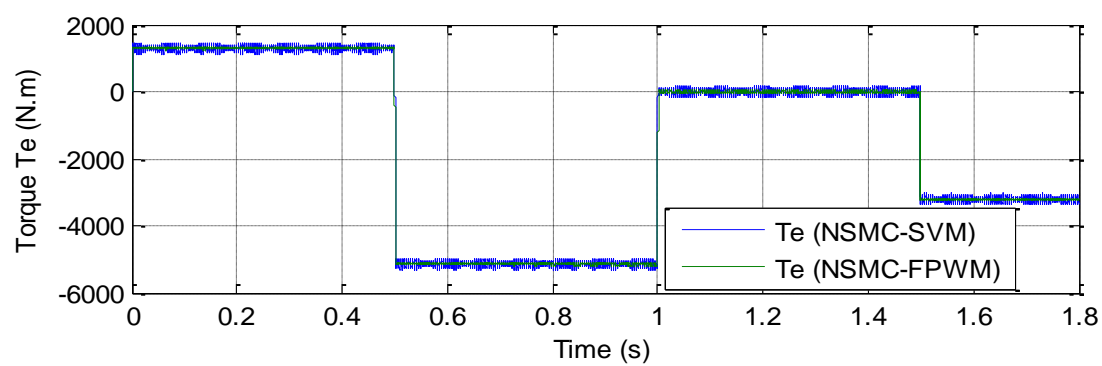

Figure 22. Electromagnetic torque

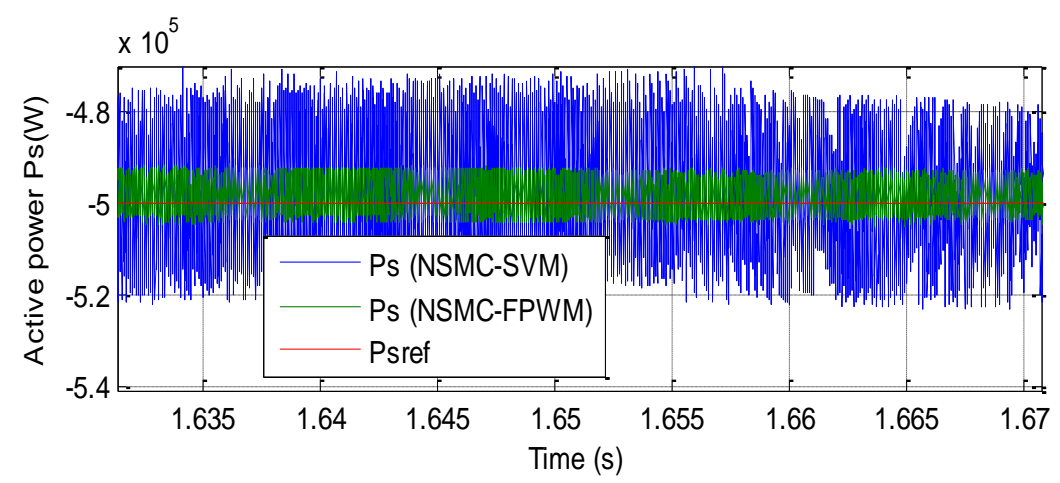

Figure 23. Zoom in the active power 


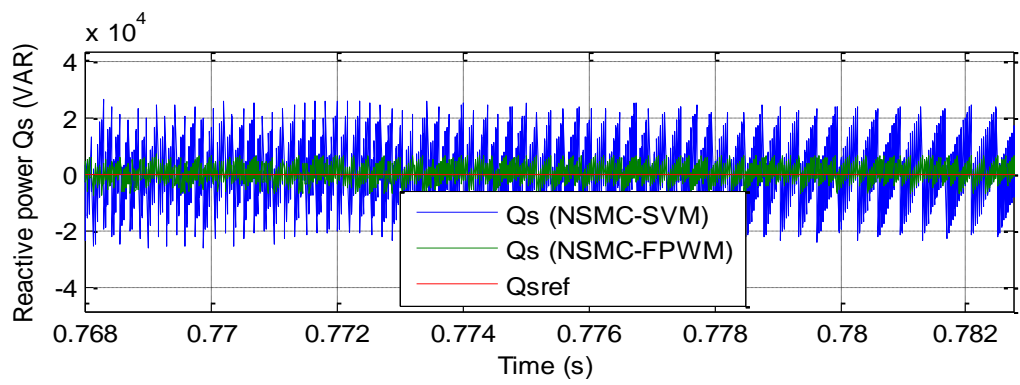

Figure 24. Zoom in the reactive power

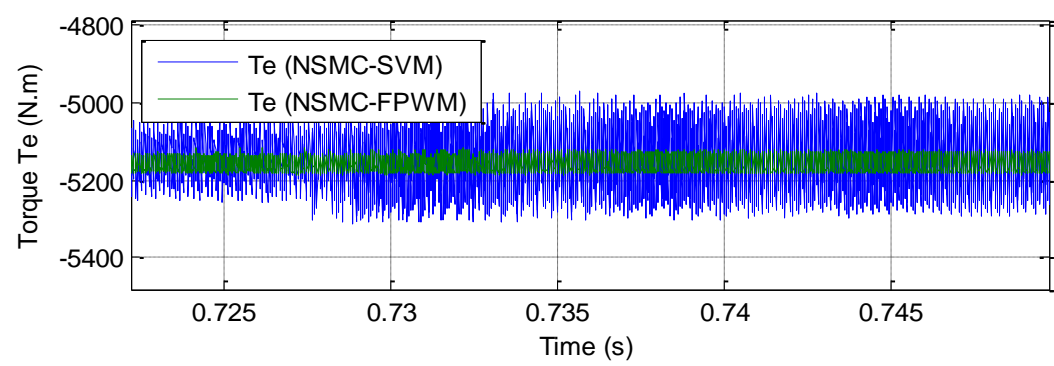

Figure 25. Zoom in the electromagnetic torque

\section{CONCLUSION}

This work presents the NSMC control scheme of the DFIG-based WECS using a two-level SVM compared with the two-level FPWM strategy. With results obtained from the simulation, it was clear that for the same operation conditions, the NSMC control with two-level FPWM technique presents good performance compared to the NSMC one using SVM and that was clear in the THD of rotor current which the use of the two-level FPWM minimize the THD of rotor current more than the SVM technique.

\section{REFERENCES}

[1] H. Benbouhenni, Z. Boudjema, A Belaidi, "DFIG - Based WT System Using FPWM Inverter," International Journal of Smart Grid, vol. 2, no. 3, pp. 142-154, 2018.

[2] Y. Bekakra, D. B. Attous, "DFIG sliding mode control driven by wind turbine with using a SVM inverter for improve the quality of energy injected into the electrical grid," ECTI Transactions on Electrical Engineering, Electronics, and Communications, vol. 11, no. 1, pp. 63-75, 2013.

[3] K. Kerrouche, A. Mezouar, Kh. Belkacem, "Decoupled control of doubly fed induction generator by vector control for wind energy conversion system," Energy Procedia, vol. 42, pp. 239-248, 2013.

[4] Z. Boudjema, R. Taleb, Y. Djerriri, A. Yahdou, "A novel direct torque control using second order continuous sliding mode of a doubly fed induction generator for a wind energy conversion system," Turkish Journal of Electrical Engineering \& Computer Sciences, vol. 25, pp. 965-975, 2017.

[5] S. Massoum, A. Meroufel, A. Massoum, P. Wira, "A direct power control of the doubly-fed induction generator based on the SVM strategy," Elektrotehniski Vestnik, vol. 45, no. 5, pp. 235-240, 2017.

[6] S. M. Tavakoli, M. A. Pourmina, M. R. Zolghadri, "Comparison between different DPC methods applied to DFIG wind turbines," International Journal of Renewable Energy Research, vol. 3, no. 2, pp. 446-452, 2013.

[7] Z. Boudjema, R. Taleb, A. Yahdou, "A new DTC scheme using second order sliding mode and fuzzy logic of a DFIG for wind turbine system," International Journal of Advanced Computer Science and Applications, vol. 7, no. 8, pp. 49-56, 2016.

[8] A. Medjber, A. Moualdia, A. Mellit, M. A. Guessoum, "Comparative study between direct and indirect vector control applied to a wind turbine equipped with a double-fed asynchronous machine article," International Journal of Renewable Energy Research, vol. 3, no. 1, pp. 88-93, 2013.

[9] H. Benbouhenni, Z. Boudjema, A. Belaidi, "Neuro-second order sliding mode control of a DFIG supplied by a twolevel NSVM inverter for wind turbine system," Iranian Journal of Electrical and Electronic Engineering, vol.14, no. 4, pp. 362-373, 2018.

[10] H. Benbouhenni, Z. Boudjema, A. Belaidi, "Direct vector control of a DFIG supplied by an intelligent SVM inverter for wind turbine system," Iranian Journal of Electrical and Electronic Engineering, In Press, 2018.

[11] H. Benbouhenni, Z. Boudjema, A. Belaidi, "DFIG-based wind turbine system using three-level neural space vector modulation technique," Majlesi Journal of Mechatronic Systems, vol. 7, no. 2, 2018, pp. 35-45. 
[12] A. Bakouri, H. Mahmoudi, A. Abbou, "Intelligent control for doubly fed induction generator connected to the electrical network," International Journal of Power Electronics and Drive System, vol. 7, no. 3, pp. 688-700, 2016.

[13] M. M. Ismail, A. F. Bendary, "Protection of DFIG wind turbine using fuzzy logic control," Alexandria Engineering Journal, vol. 55, pp. 941-949, 2016.

[14] Z. Boudjema, A. Meroufel, A. Amari, "Robust control of a doubly fed induction generator (DFIG) fed by a direct AC-AC converter," Przeglad Elektrotechniczny, vol. 11, pp. 213-221, 2012.

[15] O. Barambones, J. M. Gonzalez de Durana, "Sliding mode control for power output maximization in a wave energy systems," Energy Procedia, vol. 75, pp. 265-270, 2015.

[16] M. El-Azzaoui, H. Mahmoudi, K. Boudaria, "Backstepping control of wind and photovoltaic hybrid renewable energy system," Internationale Journal of Power Electronics and Drive Systems, vol. 7, no. 3, pp. 677-686, 2016.

[17] F. Amrane, A. Chaiba, "A novel direct power control for grid-connected doubly fed induction generator based on hybrid artificial intelligent control with space vector modulation," Rev. Roum. Sci. Techn.-Electrotechn. Et Energ, vol. 61, no. 3, pp. 263-268, 2016.

[18] A. Etxeberria, I. Vechiu, H. Camblong, J. M. Vinassa, "Comparison of sliding mode and PI control of a hybrid energy storage system in a microgrid application," Energy Procedia, Vol. 12, pp. 966-974, 2011.

[19] A. Allaoua, A. Laoufi, "A novel sliding mode fuzzy control based on SVM for electric vehicles propulsion system," Energy Procedia, vol. 36, pp. 120-129, 2013.

[20] Y. Bekakra, D. Ben Attous, "Comparison study between SVM and PWM inverter in sliding mode control of active and reactive power control of a DFIG for variable speed wind energy," International Journal of Renewable Energy Research, vol. 2, no. 3, pp. 471-476, 2012.

[21] S. E. Ardjoun, M. Abid, "Fuzzy sliding mode control applied to a doubly fed induction generator for wind turbines," Turkish Journal of Electrical Engineering \& Computer Sciences, vol. 23, pp. 1673-1686, 2015.

[22] A. Yahdou, B. Hemici, Z. Boudjema, "Second order sliding mode control of a dual-rotor wind turbine system by employing a matrix converter," Journal of Electrical Engineering, vol. 16, no. 4, pp. 1-11, 2016.

[23] Yajun Guo, Huo Long, "Self organizing fuzzy sliding mode controller for the position control of a permanent magnet synchronous motor drive," Ain Shams Engineering Journal, Vol. 2, pp. 109-118, 2011.

[24] H. Benbouhenni, "36 Sectors DTC based on fuzzy logic of sensorless induction motor drives," Research \& Reviews: Journal of Engineering and Technology. vol. 7, no. 1, pp.24-32, 2018.

[25] H. Benbouhenni, Z. Boudjema, "Speed regulator and hysteresis based on artificial intelligence techniques of threelevel DTC for induction motor," Acta Electrotechnica et Informatica, vol. 17, no. 4, pp.50-56, 2017.

[26] Z. Boudjema, A. Meroufel, Y. Djerriri, E. Bounadja, "Fuzzy sliding mode control of a doubly fed induction generator for wind energy conversion," Carpathian Journal of Electronic and Computer Engineering, vol. 6, no. 2, pp. 7-14, 2013.

[27] N. Khemiri, A. Khedher, M. F. Mimouni, "Wind energy conversion system using DFIG controlled by backstepping and sliding mode strategies," International Journal of Renewable Energy Research, vol. 2, no. 3, 2012, pp. 422435.

[28] M. Hasni, Z. Mancer, S. Mekhtoub, S. Bacha, "Parametric identification of the doubly fed induction machine," Energy Procedia, vol. 18, pp. 177-186, 2012.

[29] E. Bounadja, A. Djahbar, Z. Boudjema, "Variable structure control of a doubly fed induction generator for wind energy conversion systems," Energy Procedia, vol. 50, pp. 999-1007, 2014.

[30] Z. Boudjema, A. Meroufel, E. Bounadja, Y. Djerriri, "Non linear control of a doubly fed induction generator supplied by a matrix converter for wind energy conversion systems," Journal of Electrical Engineering, vol. 14, no. 2, 2014.

[31] B. Hamane, M. L. Doumbia, M. Bouhamida, A. Draou, H. Chaoui, M. Benghanem, "Comarative study of PI, RST, sliding mode and fuzzy supervisory controllers for DFIG based wind energy conversion system," International Journal of Renewable Energy Research, vol. 5, no. 4, pp. 1174-1184, 2015

\section{BIOGRAPHY OF AUTHOR}

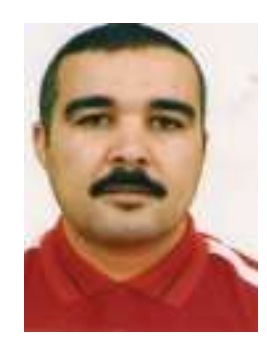

H. Benbouhenni was born in chlef, Algeria. He is a PhD student in the Departement of electrical engineering at the ENPO-MA, Oran, Algeria. He received a M.A. degree in Automatic and informatique industrial in 2017. His research activities include the application of robust control in the wind turbine power systems.

E-mail: habib0264@gmail.com; habib_benbouhenni@yahoo.com 